\title{
MANAGEMENT OF EFFICIENCY OF AGRICULTURAL PRODUCTION ON THE BASIS OF MARGIN APPROACH
}

\author{
O. V. Mishulina ${ }^{1}$, G. K. Dambaulova ${ }^{2}, \quad$ N. A. Baranova ${ }^{1}, \quad$ N. S. Gorelova ${ }^{2}$, Zh. A. \\ Utebaeva $^{3}$ \\ ${ }^{1}$ Kostanay state University \\ ${ }^{2}$ Kostanay engineering-economic University \\ ${ }^{3}$ Associate Professor of Kostanai branch of Chelyabinsk state University
}

Published online: 15 February 2017

\begin{abstract}
The article presents the main directions of realization of the concept of the margin approach in forming the economic efficiency of agricultural production.the conceptual approaches generalized and systematized to the management of production costs of agricultural products, the proposed definition of "cost control" from the perspective of the situational approach. Theways of improvement of methods of formation and calculation of costs were formulated which based on the concept of fixed and variable costs, marginal income, that generate a target profit in the organization as a reference or threshold points of its development, as well as to calculate these non-traditional local practices performance - the long and short of the lower limit of the price of the product.A simplified method of determining the contribution margin presented for possible use in economic activities of agricultural groups.Possible implementation of the presented method are shown for the formation of costs and assessment of economic efficiency of agricultural production.
\end{abstract}

\section{Justification for the research}

In the agricultural sector of the Republic of Kazakhstan is undergoing fundamental changes associated with the development of market relations, which increase the role and significance of performance management of production to achieve competitiveness and the implementation of socio-economic problems of the sector in question.

\footnotetext{
Author Correspondence, e-mail: author@gmail.com

doi: http://dx.doi.org/10.4314/jfas.v8i2s.639
} 
From this point of view, the formation and assessment of the level of economic efficiency of agricultural production necessitates the use of market-based theories of production and new methodological bases for the assessment, which is a topical scientific and practical problem. In recent years Kazakhstan's economic science and practice have moved forward, using the achievements of developed countries. This, of course, important, but clearly it is not enough without adaptation to local conditions for effective work of agrarian formations in a market economy, which there is no alternative.The insufficient development of the problem, its debatable identified the topic and range of issues.

The purpose of this scientific article is the generalization and systematization of the theory and practice of cost management and results in agricultural production based on the margin concept in the conditions of market relations. Initial setting has identified the need to address issues:

- to summarize the scientific basis for the management of expenses for production of agricultural products;

- to define directions of improvement of methods of formation and calculation of costs based on the concept of fixed and variable costs, marginal income, that generate a target profit in the organization;

- to provide a method for determining profit margin and its implementation to control the efficiency of agricultural production.

\section{MATERIALS AND METHODS}

Theoretical and methodological basis of research were the works of foreign and domestic scientists-economists in which the methods of formation and evaluation of economic efficiency of agricultural production.

\section{RESULTS}

In the market conditions of individual agricultural producer is unable to influence the price of their goods, and for profit, it can only change the volume of production that underlie the formation costs.Therefore, the decision of problems of increase of efficiency of agricultural production in a competitive market should be aimed, primarily, to the management of its costs.Analysis and synthesis of different points of view, this issue [1-6] has allowed to systematize the conceptual approaches to the management of the cost of production of agricultural products and in addition to the disclosure of the content of the concept of "cost 
control," according to the account, system and process approaches to allocate commercial (self-supporting) and situational approaches.

The first one is accounting, the basis for the concept of "cost control" is taken internal accounting system, through which the cost of production, calculation and cost management.As they follow the requirements of the financial account, provide information of a historical nature, are not suitable for managerial decision-making, they do not meet the requirements of modern development of production and increased competition.

In the second approach system is planned to consider cost management, on the one hand, as a system of interrelated methods of cost calculation and cost calculation of products, and on the other hand, purely as a system of "direct costing".In our opinion, this interpretation of the concept of "cost control" is quite reasonable and due to the fact that not only management, but also its object have their own logic, laws; they are systemic in nature.Therefore, effective management must take into consideration to be able to use.

The third approach assumes that cost control is identical to economic calculation. This point of view, in our opinion, is erroneous, because the total - cost accounting will never be equivalent in relation to the private - expense management.

According to a fourth approach (process) cost controls - the process of embodying the managerial functions with the orientation of either the control or planning. The essence of any management process is revealed through its functions. This view is most prevalent.The most important question in the theory of control applied to managing costs and is what is considered important and universal.As each management system, cost management fulfills its main purpose and key objectives through the implementation of certain functions.

Concreteness of content management indicates that it will be revealed in the functions, in each case, is filled with specific content.We agree with the viewpoint, when functions of cost management are seen as primary in relation to production, i.e. to achieve the intended result first you need to make the cost.Accordingly, the functions of cost management and the elements of implementation include: 1) development and decision-making (forecasting and planning);2) implementation of the decision (organization, coordination and regulation, activation and promotion); 3) control (accounting, analysis).

In the fifth approach - the situational, develops the main thesis of system approach: cost management of the enterprise, as a component of the enterprise management system as a whole is an open system that constantly interacts with the external environment.Therefore, the reasons for what is happening inside the system, should be sought outside it, in the situation where it really functions. This is a key concept in this approach.The situational approach 
showed that the best method of control is not, in principle, the effectiveness of any of them shall be determined by the management situation.This approach can be called the managerial concept of relativity.This is present day theory and practice of management.In the context of situational approach, we believe that cost management is a system of expressing subjectobject relations associated with the formation, distribution of costs and calculation of cost per unit of production (works, services), on the basis of information obtaining about the costs for different purposes and allowing in the relevant range to make a choice of alternative courses of action and the adoption of adaptive sequential rational managerial decisions [7].

In our opinion, this definition of the essence of "cost control" ismore fully than other reveals the real content of this category in modern conditions. The system allows: to determine the amount of funds needed for effective operation of the organization and departments;plan strategies, tactics and future operations; optimal use of resources, measure and evaluate the results of ongoing activities; to eliminate subjectivity from decision-making.Under the system of cost management depending on the type of organization, activities, purposes, control can be specialized subsystems as objects of cost management in the operating, investing and financing activities.

The construction of the system of management of operating costs of agricultural organizations requires a systematic list of objects of this control.Agreeing with the objective necessity of the existence of the accounting approach, we share the view that the object of management should be considered not the classification of costs, and grouped according to the different purposes of costs, their level, formation and structure.Based on the fact that the accounting system needs to serve a range of management objectives, there are different ways of measuring and grouping of costs.Classification of costs for management purposes must meet the main requirement is to be based on the signs, allowing differentiating the cost in various aspects.It creates the preconditions for determining the level of spending on facilities management, organization planning, accounting, control and analysis.

A central to the management costs of agricultural production always remains a target orientation and complexity merge in a single process, all parts of the operating activities. The goal is determined based on the nature of the economic mechanism of management in General - increase of economic efficiency of agricultural production.

he basis of the mechanism of cost management in agricultural organizations comprise methods of forming and costing of products (works, services) of agriculture.Therefore, for correct choice of those or other systems and methods of formation and of cost calculation and their application requires critical analysis of various methods as well as the lessons learned in 
domestic and foreign practice.

Investigations of the existing systems and methods of formation and of cost calculation in agriculture have shown that they are not adapted to new challenges and demands in the market [8]:

- do not fulfill their analytical and control functions;

- when calculating the cost of domestic practice, the goal is to determine the profitability, not the process of its formation;

- information on cost price with full allocation of costs are not useful for operational management of production efficiency in the organization;

- exclude the possibility of applying the marginal approach, the adoption on this basis of optimum administrative decisions on the system "input - output - outcome - efficiency" with the aim of increasing economic efficiency of agricultural production, and also to simulate a variety of control system inputs and outputs.

As a result of research the main directions of improvement of methods of formation and of cost calculation in agriculture to improve the economic efficiency of production in a market environment are recognized:

- adaptation of existing accounting systems to current economic conditions;

- the further development of their analytical and control functions;

- create different from the traditional methods of obtaining information on the cost to their division into fixed and variable parts depending on the functional changes of the activities of agricultural groups.

In line with this, we carried out a systematic restructuring of the current item cost items for calculating the cost of production for the purpose of managerial decision-making, which takes into account the opportunity cost of using its own production resources producers. When the disaggregation and rearrangement of the existing articles of the cost come not only from the above factors, but also of the classification of costs according to their relation to production volume (works, products).We offer a range of articles and elements of expenses allows taking into account all costs borne by the economy as a whole, its departments in the context of each production process.In addition, there are articles and items of cost the basis of groups based on such characteristics of classification of costs both in relation to technological process of production;economic content; the method included in the cost; types of products (works, services); relative to the volume of production.An important feature of the proposed groupings of costs is that it creates opportunity identification and analysis, marginal income and profit, the conditions of control of economic results in agriculture not only after the end 
of the production cycle, but also on the stage of the end of each production process, as well as by responsibility centers.

The margin approach is based on fundamentally new methods of economic analysis, enabling to determine the limit values for the characteristics of economic activities.In this connection it is necessary to separate the production direction of the farm into smaller units - the production processes ( 1 hectare, 1 head, 1 cattle-place).They are characterized by a certain ratio requirements in factors of production and the outputs, or the ratio of input-output, tie together technology, organization of production and the economy, and assessment of level of formation of expenses and managing profitability in a market environment is carried out using the limit values.

Thus, the implementation of the margin approach in agriculture can:

- deepen the analysis of the costs and shaping the economic efficiency of production;

-the object of the assessment to include only those revenues and expenses for the selected approach are considered as directly associated with the object;

- to consider the nature of the behavior of costs depending on volume;

- more precisely calculate the impact factors on the change in the amount of profit and on this basis, more effective management of process of formation and prediction of its value;

- to identify causal relationships, i.e. "the levers" control costs; control and plan expenditures and results;

- to determine the minimum critical volume of production;

- to establish a safety zone commodity, i.e. risk assessment;

- calculate the required sales volume to obtain a predetermined value of profit;

- to justify the optimal variant management solutions (maximizing marginal revenue), concerning pricing, changes in production capacity, volume and structure of production in the context of resource constraints, choice of technology process and production method.

he margin approach is based on the concept of alternative, fixed and variable costs, marginal income, which allows us to generate a target profit in the organization as a reference or threshold points of its development, as well as to calculate these non-traditional local practices performance - the long and short of the lower limit of the price of the product.All of this enables the formation of costs and their evaluation on the system "input - output outcome - effectiveness" for individual products, sectors, divisions and General agricultural organizations with the following indicators:

- profit margins;

- threshold point of production and profitability (threshold prices); 
- break-even point (the income threshold);

profit;

- entrepreneurial income;

- the return on the factors of production: labour, land and capital (fixed and working capital).

The presence of these positive characteristics of the marginal approach is the need to further develop and Refine performance indicators that would allow a more objective approach to definition and assessment of the cost of production of separate types of agricultural products and agriculture as a whole in the conditions of market relations.A study of methods of determining the main indicator of marginal income that is used in domestic as well as foreign theory and practice allowed us to simplify the method of its calculation and to make possible its use in economic activities, because the approach to the calculation of this indicator, described in theory, in practice it is quite difficult [9-11].It is proposed to consider only proportional and variable costs of the production process and its cost along with commercial products to include on-farm production and consumption through market relations. The cost of working capital note on the general level, and it is not at the level of the production process (table 1).

Table 1. Method of determining marginal income

\begin{tabular}{|l|c|c|}
\hline \multicolumn{1}{|c|}{ Signsofcomparison } & $\begin{array}{c}\text { The calculation in } \\
\text { applied Economics }\end{array}$ & $\begin{array}{c}\text { The calculation using a } \\
\text { simplified method }\end{array}$ \\
\hline Revenues & $\begin{array}{c}\text { he amount is only a } \\
\text { commodity output at } \\
\text { prices of realization }\end{array}$ & $\begin{array}{c}\text { the amount of value of } \\
\text { production (commodity } \\
\text { production and production } \\
\text { for on-farm consumption) }\end{array}$ \\
\hline Variablecosts & all costs are treated as \\
& $\begin{array}{c}\text { variables } \\
\text { proportional variable costs } \\
\text { without the overhead of } \\
\text { working capital, land and } \\
\text { profitmargins }\end{array}$ & permanent workforce \\
\hline Application & the optimization \\
& calculation & $\begin{array}{c}\text { summative calculation } \\
\text { profitability calculations }\end{array}$ \\
\hline
\end{tabular}




\begin{tabular}{|l|c|c|}
\hline & $\begin{array}{c}\text { the definition of } \\
\text { competitiveness }\end{array}$ & planning and consulting \\
\hline Thecomparisonbetweenorganizations & $\begin{array}{c}\text { not possible, as the } \\
\text { availability of resources } \\
\text { and cost components } \\
\text { can be different }\end{array}$ & $\begin{array}{c}\text { not possible, because } \\
\text { there is no unified } \\
\text { nomenclature of } \\
\text { proportional variable costs } \\
\text { for the accounting objects }\end{array}$ \\
\hline
\end{tabular}

This will reduce the number of calculations and to visualize the formation of profit. For those times when for working capital, basic labor and agricultural lands occur variable costs, it is proposed the calculation of contribution margin of the production process to carry on the stages.

On the basis of profit margins and business income we may determine pay off if used in a particular production process, labour, land and capital. The difference between profit and entrepreneurial income is that in the calculation of the latter takes into account the opportunity costs for own production factors.

Evaluation of the efficiency of the production process could be conducted by comparing the sales price of a unit of production with the cost of production of her unit.If the calculation is restricted to the accounting for variable costs, then the result is a short-term lower boundary prices at which the continuation of production with existing assets economically feasible, we are talking about the threshold of production. When calculating the threshold for the production of intermediate amounts formed. It facilitates visibility of the calculations and allows for a deeper interpretation of the formation of the production efficiency.

The allocation of the total costs of production per unit of main products yields a value of the threshold of profitability or long-term lower boundary of the production cost. The relationship between the various indicators of profitability of the production process is presented in table 2. 
Table 2. Correlation of indicators of profitability of the production process in agriculture

\begin{tabular}{|c|c|c|c|c|}
\hline $\begin{array}{c}\text { The level of } \\
\text { production } \\
\text { efficiency }\end{array}$ & Profitmargins & Entrepreneurialincome & Thepaybackfactor & $\begin{array}{c}\text { The price of } \\
\text { products }\end{array}$ \\
\hline Inefficient & $<0$ & $<0$ & $\begin{array}{c}<\text { the costs use of } \\
\text { factor }\end{array}$ & $<$ Thresholdprice \\
\hline Theefficientfrontier & $=0$ & $=0$ & $\begin{array}{c}\text { the costs use of } \\
\text { factor }\end{array}$ & Thresholdprice \\
\hline Effectively & $>0$ & $>0$ & $\begin{array}{c}>\text { the costs use of } \\
\text { factor }\end{array}$ & $>$ Thresholdprice \\
\hline
\end{tabular}

The considered assessment of costs and benefits of the production process are in the relationship between them and cannot be considered separately from each other.Each indicator separately allows determining cost-effectively the production of specific agricultural products in the short and long term. When this phenomenon is not observed when one indicator confirms the economic efficiency and the other denies it.

The proposed method of forming the cost of production can be used in agricultural organizations in two aspects.First, for the compilation of summative calculations determine the level of costs and assessment of production efficiency, and secondly, as a tool to identify the highest economic efficiency of production and the extent of its achievements in the organization. This gives the opportunity to expand the analysis and control necessary to ensure objective assessment of development costs and results, and the implementation of international comparisons in terms of integration of Kazakhstan in world economic space.

On the basis of methodological approaches we assess efficiency in grain production of the farm "Nurtilek" (tables 3, 4).

For sowing wheat, mostly, their own seeds is used (90\%), only a small percentage of seed purchased $(10 \%)$ required to upgrade the quality of sown seeds.Own seeds are estimated according to the actual sales prices on the principle of alternative costs (storage, drying, cleaning, grading). 
Table 3. Formation of marginal income when growing spring wheat of the first crop after steam in FH " Nurtilek "

\begin{tabular}{|c|c|c|c|}
\hline \multicolumn{4}{|c|}{$\begin{array}{l}\text { Production process: Cultivation of wheat varieties "Omsk - 18" } \\
\text { Unitofcalculation: } 1 \text { ha }\end{array}$} \\
\hline Thevalueofproduction & $\mathrm{p} / \mathrm{ha}$ & tenge/p & tenge/h \\
\hline Yield & 14,6 & & \\
\hline commercialgrain & 13,1 & 3570 & 46767 \\
\hline Grainwaste & 0,73 & 944 & 689,12 \\
\hline Straw & 7,3 & 180 & 1314 \\
\hline \multicolumn{3}{|l|}{ Price, all } & 48770,12 \\
\hline \multicolumn{4}{|l|}{ Variablecosts } \\
\hline Seeds & $\mathrm{Kg} / \mathrm{h}$ & tenge/p & tenge/h \\
\hline Private & 126 & 3370 & 4246,20 \\
\hline \multirow[t]{2}{*}{ Purchase } & 14 & 5040 & 705,6 \\
\hline & $\mathrm{kg}, \mathrm{l} / \mathrm{ha}$ & tenge/l, $\mathrm{kg}$ & tenge/ha \\
\hline Nitrogen & 64,3 & 88,8 & 5709,8 \\
\hline Phosphoric & 17,4 & 106,08 & 1845,8 \\
\hline Potassium & 24,1 & 26,02 & 653 \\
\hline \multicolumn{3}{|l|}{ Fertilizer ofall } & 8208,6 \\
\hline \multicolumn{3}{|l|}{ Means of protection of plants, all } & 1385,2 \\
\hline \multicolumn{3}{|l|}{ Themechanizationprocess } & tenge/h \\
\hline \multicolumn{3}{|l|}{ Repair } & 2960 \\
\hline \multicolumn{3}{|l|}{ Lubricants } & 3310 \\
\hline \multicolumn{3}{|l|}{ Pay } & 1848 \\
\hline \multicolumn{3}{|l|}{ Othercosts } & tenge/h \\
\hline \multicolumn{3}{|l|}{ Insurance } & 4628 \\
\hline \multicolumn{3}{|l|}{ Drying (partially) } & 590,4 \\
\hline \multicolumn{3}{|l|}{ Variablecosts, all } & 27882 \\
\hline \multicolumn{3}{|l|}{ Profitmargins } & 20888,12 \\
\hline \multirow{2}{*}{\multicolumn{3}{|c|}{$\begin{array}{l}\text { The need for working capital } 50 \% \text { variable costs } \\
\text { Cost of working capital (the estimated rate of } 18 \% \text { ) }\end{array}$}} & 13941 \\
\hline & & & 2509,4 \\
\hline
\end{tabular}


The cost of seeds from own production include cost of seed treatment. The cost of the purchase of seed is calculated at market prices.

Table 4. Formation of marginal profit in the cultivation of spring wheat second crop after couple in FH" Nurtilek "

\begin{tabular}{|c|c|c|c|}
\hline \multicolumn{4}{|c|}{$\begin{array}{l}\text { Production process: Cultivation of wheat varieties "Omsk - 18" } \\
\text { Unitofcalculation: } 1 \text { ha }\end{array}$} \\
\hline Thevalueofproduction & $ц / \Gamma$ & тенге/ц & тенге/г \\
\hline Yield & 12,6 & & \\
\hline commercialgrain & 11,3 & 3570 & 40341 \\
\hline Grainwaste & 0,63 & 944 & 594,72 \\
\hline Straw & 6,3 & 180 & 1134 \\
\hline \multicolumn{3}{|l|}{ Price, all } & 42069,72 \\
\hline \multicolumn{4}{|l|}{ Variablecosts } \\
\hline Seeds & $\mathrm{K \Gamma} / \Gamma$ & тенге/ц & тенге/г \\
\hline Private & 140 & 3370 & 4718 \\
\hline \multicolumn{4}{|l|}{ Purchase } \\
\hline & кг, л/Г & тенге/л, кг & тенге/Г \\
\hline Nitrogen & 62,13 & 88,8 & 5517,2 \\
\hline Phosphoric & 15,57 & 106,08 & 1651,6 \\
\hline Potassium & 20,55 & 26,02 & 534,8 \\
\hline Fertilizer ofall & & & 7703,06 \\
\hline Means of protection of plants, all & & & 3166,6 \\
\hline \multicolumn{4}{|l|}{ Themechanizationprocess } \\
\hline Repair & & & 3360 \\
\hline Lubricants & & & 5224,6 \\
\hline Pay & & & 2066 \\
\hline Othercosts & & & тенге/г \\
\hline Insurance & & & 4958 \\
\hline Drying (partially) & & & 925,6 \\
\hline Variablecosts, all & & & 32119,4 \\
\hline Profitmargins & & & 9950,32 \\
\hline The need for working capital $50 \%$ variable costs & & & 16059,7 \\
\hline Cost of working capital (the estimated rate of $18 \%$ ) & & & 2890,8 \\
\hline
\end{tabular}


When mineral fertilizers and means of plant protection costs per 1 ha are determined by multiplying the required amount (per $1 \mathrm{ha}$ ) on the price and the number of treatments.

When determining the cost of mechanization is necessary to distinguish between costs of using their own agricultural equipment and involved.The cost of mechanization technology includes private repair costs, fuel and lubricants. To determine the variable costs use the normative data of individual agricultural machines and units and process operations.

When processing a pair of marginal income per 1 ha value is negative $-4437,3$ tenge because of this process do not receive commodity grain (table 5).

Table 5. Marginal costing treatment of 1 ha pair

\begin{tabular}{|l|c|}
\hline Performance of the production process & Tenge \\
\hline Variablecosts: & 568,4 \\
\hline Repairofequipment & 3524,8 \\
\hline lubricants & 344,1 \\
\hline salary & $-4437,3$ \\
\hline Profitmargins & 2218,6 \\
\hline The need for working capital & 399,4 \\
\hline Costsworkingcapital & \\
\hline
\end{tabular}

When growing wheat as the first crop after steam margin yield is 20888,12 tenge/ha. The variable costs of the production process is equal 27882 tenge/ha, from them $29,4 \%$ of the cost of fertilizer, $17,6 \%$ - the cost of seeds, $10.6 \%$ of the repair costs of agricultural machinery, $11.9 \%$ of the cost of fuel and lubricants, $6,6 \%$ - remuneration of operators and $18.7 \%$ other. When growing wheat second crop after a couple of marginal income is equal 9950,32 tenge/ha.The variable costs of the production process are 32119,4 tenge/ha.The increase in variable costs linked to the use in the production process of plant protection products, their share in the structure of variable costs is 9.9 percent.Also increased costs for fuel and lubricants $-16,3 \%$, as in the technology of cultivation appeared two operations: autumn tillage and chemical weeding.

Define a general margin income from wheat growing in the farm for the future (table 6).

The highest interim profit (margin income) to cover fixed costs brings the wheat is the first crop after steam.It accounts for $77,3 \%$ of the total profit margin in grain production $-6120,2$ thousand tenge. 
Table 6. Total profit margins in grain production for the future

\begin{tabular}{|c|c|c|c|c|c|}
\hline Productionprocesses & $\begin{array}{c}\text { Area, } \\
\text { ha }\end{array}$ & $\begin{array}{c}\text { The cost of } \\
\text { production } \\
\text { from 1 ha, } \\
\text { tenge }\end{array}$ & $\begin{array}{c}\text { Variable } \\
\text { costs per 1 } \\
\text { ha, tenge }\end{array}$ & $\begin{array}{c}\text { Margin } \\
\text { yield from } \\
1 \text { ha, tenge }\end{array}$ & Totalmarginincome, \\
tenge
\end{tabular}

Determine the need for production resources required for the planned production of grain crops (table 7).

Table 7. the need for production resources on the planned volume of grain production per 1

ha

\begin{tabular}{|c|c|c|c|}
\hline Productionprocesses & Theground, ha & Labor, manhour. & Capital, tenge \\
\hline Pair & 1 & 5,4 & 5320,8 \\
\hline Wheat -first & 1 & 14,5 & 15125,4 \\
\hline Wheat- second & 1 & 11,5 & 17282 \\
\hline
\end{tabular}

The need for working capital is half of total variable costs. The need for land for the cultivation of crops depends primarily on the vegetation period of culture.So only single maybe use of land, these processes need to be 1 ha, labour demand is taken into account in marginal costing, working stages.The total demand for man - hours for all production processes amounted to 8973,4 man - hours. the farm has 9975 man - hours the reserve is 1001,6 man - hour.The need for basic capital is calculated as a medium to the associated value.

In calculating the profit in grain production for the future in the above method, there remains a multilateral relationship between individual economic parts of the enterprise, as well as economic interrelations are presented in an intelligible plan using this method:

First, you can easily cover the internal economic relationships of the company and to make a rational decision; 
Second, this method allows you to use it without the use of the computer in any household.

On the basis of the marginal income of the individual manufacturing processes, the total marginal income calculated in grain production. This is done by multiplying the individual marginal income and volumes of the performed processes in the grain industry.Total margin income in the economy amounted to 7921,9 thousand tenge, from which must be covered overhead.

In determining the profit in grain farming of marginal income subtract fixed costs of production.Information about fixed costs is shown in table 8. Fixed costs do not depend on the volume of grain production, so they are not included in marginal costing.

Table 8. fixed costs for the future

\begin{tabular}{|l|c|}
\hline Costitems & Thousand tenge \\
\hline Depreciation & 1039,2 \\
\hline Maintenanceofbuildings & 2,0 \\
\hline Othercosts & 43,6 \\
\hline Total & 1084,8 \\
\hline
\end{tabular}

To find the profit in grain farming of marginal income subtract fixed overheads (table 9).

Table 9. formation of the profits of the farm for the future

\begin{tabular}{|l|c|}
\hline Indicators & Thousand tenge \\
\hline Totalmarginincome & 7921,9 \\
\hline Fixedoverheads & 1084,8 \\
\hline Profitfromoperatingactivities & 6837,1 \\
\hline The opportunity cost of using capital & 3365 \\
\hline Economicprofit & 3472,1 \\
\hline
\end{tabular}

An cconomic profit from the production of grain amounted to 3472,1 thousand tenge, and accounting profit - 6837,1 thousand tenge.

On the basis of the calculations the last result indicator will determine: level of profitability of grain production in the farm (table 10). 
Table 10. Economic performance in the farm "Nurtilek" on prospect

\begin{tabular}{|c|c|c|}
\hline Indicators & $2011-2016$ & On prospect \\
\hline The total amount of profit, thousand tenge & 4832,5 & 6837,1 \\
\hline The full cost of production, thousand tenge & 7792,3 & 10518,6 \\
\hline $\begin{array}{c}\text { The level of profitability of crop production as a } \\
\text { whole, } \%\end{array}$ & 62,0 & 65,0 \\
\hline
\end{tabular}

The table showsdata analysis that the planned increase in grain yield from 10.6 to $13.6 \mathrm{t} / \mathrm{ha}$ due to application of measures of intensification will entail additional over-spending and the growth of the total production costs for 2726,3 thousand tenge, or 34.9 per cent.However, the growth rate of grain yields outpaced the growth of the additional cost, in the end, there is an increase accounting profits in the economy of $41.5 \%$ compared to 2011 - 2016 and the profitability by 3 points.

\section{CONCLUSION}

The transition to a market system in the Republic of Kazakhstan determined a radical transformation of forms of ownership and management,it has led to the concept of change management and economic development, the need to use market theory of production efficiency and new methodological bases its assessment - margin approach.

In this regard, it is not enough to fix the target profit in a certain annual rate, because such information can be used to improve the efficiency of business activities and the goal of an entrepreneur to get into private sub-goal.Such a model for the formation of economic efficiency of agricultural production in market environment is the relationship "cost - volume - profit".It is based on the concept of fixed and variable costs, marginal income.This enables to make the profit target in the economy in the form of threshold points of its development.

\section{BIBLIOGRAPHY}

1. Lapygin, $\mathrm{Yu}$. N. The cost management in the enterprise: planning and forecasting, analysis and cost minimization: a practical guide / Y. N. Lapygin, N. G. Prokhorov.- M.: Eksmo, 2015.- $128 \mathrm{p}$.

2. The cost management: a strategic guide / David P. Doyle; [translated from English. I. V. Kozyr, and N. Sologub].- M.: VoltersKluver, 2016.-264 p.

3. Kolerov, S. A. The cost management / S. A. Kolerov. - SPb.: Peter, 2012. - 160 p.

4. Labzunov, P. P. The control of prices and costs in a modern economy / p. P. Glazunov. - 
Moscow: Book world, 2013. - 288 p.

5. Lebedev, V. G. The cost management in the enterprise / V. G. Lebedev, T. G. Drozdova, V. P. Kustarev. - M.: Book on demand, 2012. - 592 p

6. Gorelov, A. N. The concept of cost management in agricultural enterprises// Problems of the sector.-2014.- No. 4.- P. 26-32.

7. Mishulina, O.V. Situationalapproachtocostmanagement attheenterprise// тери лы IX междун родной н учно-пр ктической конференции « ук и иннов ции», .2. кономические н уки, ольш , 2013.- .-74-78.

8.MishulinaO. V., Gorelova, N. S. Improvementintheoperatingprofitinthepeasant (farm)// Problemsofthesector.- 2015.- No. 4.- P. 51-58.

9. Kazakova, N.A. Management analysis in various industries/N.A. Kazakova. - M.: Publisher: Infra-M, 2014- 288 p.- Mode of access: http://www.knigafund.ru (accessed 10.11.2016).

10. Kazakova, N.A. The analysis and control of efficiency of agricultural production: theory and practice / N.A. Kazakova, A. M. Lekhanova. - M.: publishing house of Russian state agrarian University-MTAA named after K. A. Timiryazev, 2014. - 128 p.

11. The efficiency of agricultural production (guidelines) / ed. by I. S. Sandu, V. A. Slobodina, V. I. Nechaev, M. V. Kosolapova, V. F. Fedorenko. - M.: FSBSI "Rosinformagrotech", 2013. - 228 p.

\section{How to cite this article:}

Mishulina O V, Dambaulova G K, Baranova N A, Gorelova N S, Utebaeva Zh. A. Management of efficiency of agricultural production on the basis of margin approach. J. Fundam. Appl. Sci., 2017, 9(1S), 49-64. 